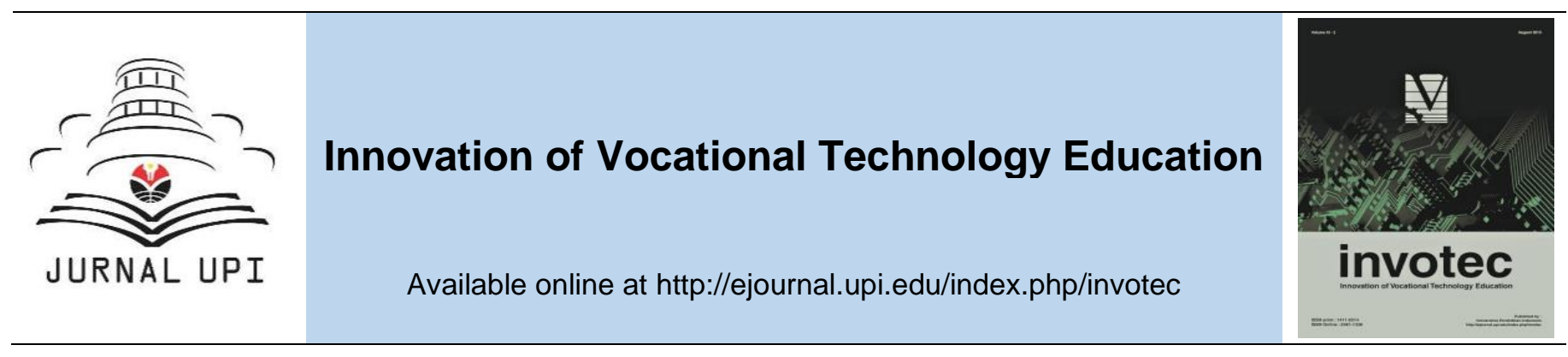

\title{
GUIDANCE AND COUNSELING DESIGN FOR WORKERS IN CREATIVE INDUSTRY SECTOR
}

\author{
Kamin Sumardi \\ Universitas Pendidikan Indonesia, Indonesia
}

ARTICLE INFO

Article history:

Received 21 December 2016

Received in revised form 6

January 2017

Accepted 20 January 2017

Available online 28 February 2017

Keywords:

creative industry,

creative economy,

counseling and guidance

Corresponding author:

kaminsumardi@upi.edu

\author{
A B S TR A C T
}

Creative industry is one of sectors that most resistant to the economic crisis. The creative industry is a group of industries that relies on individual creativity, skill and talent that has ability to improve living standards and provide employment through creating ideas and exploiting copyright. To optimize their performance they need guidance and counseling which are appropriate to their characteristics and needs. The aim of this study is develop a model of guidance and counseling which is specific and relevant to the needs of workers in the creative industries. The study used research and development method. Additionally, the study used interviews and observations as the research instrument. The location of study was the district of creative industries in Bandung. The research subjects were 3 creative industries. The results of the study show that counseling system toward the employees has not been implemented comprehensively and sustainably. The guidance and counseling were implemented only on certain aspects related to the quantity and quality of the products. The guidance was implemented only by such industries and has not involved other parties. The conclusion of the study concludes that the creative industries need a model of guidance and counseling which would help them to develop their activities and products must be in accordance with national standard in order to be more competitive.

\section{Introduction}

Guidance and counseling program has not touched the areas that should be oriented. The progress of industry in China, Taiwan, South Korea, Thailand and other Southeast Asian countries are supported by their creative industries. These industries are standardized with national labor standards and competences through guidance and counseling program that fits the needs of the creative industry (Alias \& Hassan, 2013). The guidance and counseling program are very closely interrelated. Both of these programs should embrace and provide solutions in the face of economic competition and the labor market. By applying 
appropriate design and model of guidance and counseling practitioners in creative industry enable to have better knowledge, attitude and skills competency. They are expected to be more creative, innovative, and productive, so that later they can succeed in the face of various problems and challenges for entering a better future.

The design of guidance and counseling for creative industry in general is part of educational development of competence of attitudes, knowledge, and skills in an integrated (Kuswana, 2013). The competence of graduates should have a qualification of graduates' capabilities that includes attitudes, knowledge, and skills in accordance with Indonesian National Qualification Framework (INQF or known as KKNI Kerangka Kualitas Nasional Indonesia). The creative industry is a group of industries which consists of various types of industries, each of which have relevance in the process of exploitation of ideas or intellectual property into a high economic value that can create prosperity and jobs (Afiff, 2012). Ministry of Trade of Indonesia stated that the creative industry is an industry that is derived from the utilization of creativity, skill and talent of individuals to create prosperity and jobs by generating and exploiting creativity and inventiveness of the individuals. Industry has character, among others, production activities have added value, the products can be mass-produced in bulk quickly and accurately, the process of production involves machinery and science, has a measurable target customers, and the innovation of products can be done sustainably.

Establishing framework through grouping creative industries will take place in determining the development strategy. By knowing the intensity of the use of natural resources in creative industries, the sector development strategy needs to pay attention to certain aspects of natural resource management policies in such industries. In addition, government policies within various institutions that touch four different dominant aspect in the creative industries (arts and culture, media, design, and science and technology) will affect the creative industry sector concerned (Paryono, 2013). Creative industries have characteristics of creativity that holds such a central role as the main power source. Creative industries require more creative resources which are derived from human creativity rather than physical resources.

The purpose of guidance and counseling is in order that guided individuals enable to adapt, solve problems, develop life skills, develop a positive attitude, have a sense of responsibility, plan the future, achieve the task of development and achieve life welfare. The principles of guidance and counseling are oriented for all. Guidance is a process that is embedded in all educational activities and should be studentcentered. The activities of guidance include all the competences of development individuals and should be provided as ongoing basis as well as maintaining the confidentiality of the data on guided individuals. In addition, it should use a variety of approaches that are appropriate to the person who guided and cooperate with other institutions dealing with guidance and counseling services.

\section{Method}

This study applied research and development method in which was completed the stages within research and development to produce a final document. In general, the research and development procedures are as follows: a preliminary included survey to the creative industry centers in Bandung area; empirically examined or analyzed the educational background of the practitioners of the creative industries. The draft of initial design of the guidance and counseling program which is required by KKNI was validated by experts and practitioners through a number of discussions. Furthermore, it was reflected and revised by the researchers, and then ready to be tested. The tests were done on a small scale by taking 3 samples of the creative industries. After this section, the design of guidance and counseling program was ready to be tested on a large scale. The final step in this section is seminar of the results and dissemination, and continued by finalization of the guidance and counseling program that would be applied to the creative industries. 


\section{Result and Discussion}

The results of the research indicated that guidance and counseling program in which includes attitudes, knowledge and skills was needed by the employees. The guidance and counseling on the attitudes of the employees embraced attitude towards work, how to work, relationship among employees, management and the environment. This guidance and counseling were needed continuously in order to become a habit of the employees and aimed to improve employees' performance related to the production process. However, the process of this program took longer than other programs.

Guidance and counseling to employees was conducted to "sharp" their skills covering all aspects of employment. Guiding employees embraced attitude, company and labor rules, the use of tools and machinery, work procedures/workflow, health and safety, and other relevant topics. The guidance program was not conducted specifically, but it was doing by practicing in the field weekly or temporarily because of the limited budget of the industries. Guidance and counseling program was conducted by internal human resources, not invited expert(s) from external agencies because they know exactly what they needed for their employees. The guidance and counseling program included guidelines 5-R, namely neat, industrious, rehearsal, friendly, maintained, and 4-M, namely human, methods, materials, machines.

Most of creative industries do not use comprehensive counseling and guidance. So most of them also do not have the competency standards and associated with the standard of industry. Workers in creative industries require special guidance and counseling programs that fit their needs. Guidance and counseling program ever undertaken by some industries, but it had not yet fully fit their needs so that the necessary design developed from the needs of workers in the creative industries. Employment in the creative industries do not have a standard of performance, competence, networking, innovation, knowledge and skills so that the necessary guidance and counseling program which was comprehensive and covers all aspects of the creative industries using labor standards and national competence.

Metamorphosis of guidance and counseling services is in line with the diversity of work and demands greater expertise in decision-making. The core model of career development programs not only help to prepare individuals to become ready for the workforce, but also to improve the quality of the service in order to be able to deliver every individual to be able to plan and direct the work in accordance with the purpose of his life (Savickas and Walsh, 1996). Moreover, in the 21st century, they should be able to connect their own purpose, both in the process and in the practice, to the organizational needs all time or lifelong career development (Savickas et. al, 2009; Super, 1990; Gutteridge, Leibowitz \& Shore, 1993b).

The principle of guidance and counseling service in the creative industries based on several aspects, they are a dynamic situation, related to context, and individual activities with the environment so greatly influenced by the perspective of national and global, the necessary core service which is more comprehensive than just guidance, for example, career and stress counseling in financial sector to explore the possibilities and learn to plan, reduce stress or anger management, the problem of insecurity, unemployment and adjustment problems of work that should be available and accessible to every individual within the scope of the wider scope (Collin and Watts, 1996). In addition, the importance of approach focuses on the primary goal of service and obtaining the healthy learning experience in every nation (Krumboltz, 1996).

Guidance and counseling services should prepare creative industry workers to get ready to enter the world of work and be able to increase their subjective well-being. The economic prosperity of a nation depends on the ability of its citizens to learn the relevant skills and characteristics, and learn to adapt to constantly changing work environment. The function of career guidance is as a market maker. It means that education, training and labor markets can work more effectively if people have information which is in accordance with the changes that occur in any labor market. In changing world, the role of career guidance is significant. The potential of career guidance impact on welfare and have attracted the attention of the public (Robertson, 2013). Career guidance has similarity with therapeutic counseling in an impact on life and promotes positive engagement in work and learning, which is associated with mental health and wellness benefits. 
Creative workers need to work with a solid knowledge and continuous updated information. The inability of the creative industry workers in the face of changes in the consolidation period can lead to dissatisfaction in the works that would affect the process of the work which is their responsibility. Furthermore, this condition will also affect the quality of work extensively, so it was important to improve the competence of adaptability career and work satisfaction. Competence of adaptability develop an individual's competence in making decisions, planning, exploring careers, and build a feeling of strength and life satisfaction as a major factor of economic success of a worker in the 21st century, work performance, turnover, and concentration, while at work (Savickas, et. al, 2009).

Aspects of job satisfaction refer to positive emotional states resulting from the assessment of job or work experience person and related to well-being (welfare) (Lent \& Brown, 2008). There are four main factors of job satisfaction: the work itself, recognition, context and environment. Employees who are satisfied with their work will certainly commit to their organizations if they are satisfied with the nature of the work, if they are satisfied with the boss and co-workers, and if they enjoy a sufficient compensation and opportunities for promotion. Job satisfaction is also related to share the values of cooperation among employees and together in building the organization.

The model of guidance and counseling services for career is developed comprehensively in which give a mandate to the counselor to work full time in the service model that contains programs that would be implemented and put the operation of guidance and counseling services through five phases: planning, designing programs, implementing programs, evaluating and development (Gysberg and Henderson, 2001). The implementation of guidance and counseling services as mentioned above is an attempt to provide assistances to the creative industry workers to be able to think, feel, and behave healthy in the face of the workload so that they can develop themselves optimally.

Guidance and counseling program of comprehensive development consists of four main components: (1) basic services of counseling, (2) responsive services, (3) individual planning systems, and (4) support system. The basic of the premise and the main service principally focused on models of guidance and counseling services for adults. The basic service of guidance is aimed to help workers in the creative industries to develop basic skills for life and work. The components of the basic services are fundamental to the development of the guidance and counseling program. Responsive service is aimed to intervene the matters of personal workers in creative industries that appear immediately and felt at that time with regard to social issues, personal matters, and/or the development of education or training issues.

The service is preventive and remedial in which preventive by providing interventions toward creative industry workers to avoid the unhealthy or inadequate choices to enable them to make decision in certain situations and remedial by providing interventions to the workers in creative industries that has had a wrong choice or they do not have competence in solving the problem. Priority for delivering the services is tailored to the needs of each worker creative industries. Provision of consultancy services is formed both individually and in small groups, observing the creative industry workers to identify problems, consultation to make reference program to related party, coordinating with other experts, and monitoring the progress of the creative industry workers.

Individual planning is to guide the creative industry workers to plan, monitor and manage the plan of education or training, and develop social or personal needs. Counselors can use various sources of staff, information and activities focusing on the creative industry workers and help them individually to develop/implement personal plans. Support system is more focused on providing service and management activities that indirectly beneficial to the creative industry workers. The service includes consultation with all stakeholders; support for education or training program on community efforts to related industries; participation in various activities in order to improve the implementation of improved planning purposes and cooperation in carrying out relevant researches; provide input to the decision-makers in the education curriculum and/or training, based on the perspective of the creative industry workers.

The evaluation of guidance and counseling services models to creative industry workers is more focused on the evaluation process conducted in each step in order to obtain feedback for improvements in follow-up 
activities. Through the evaluation of the design service models, counselors can collect data on the actual implementation by describing the nature and frequency of contact with the creative industry workers, job descriptions, surveys, elected interviews to the members of the user groups and the use of time and task analysis procedures.

\section{Conclusion}

Guidance and counseling to employees has not implemented comprehensively and sustainably. Guidance and counseling was performed only on certain aspects relating to the quantity and quality of the products. Guidance was only done by the industries and has not involved other parties. The model of the guidance and counseling for creative industries workers must meet the following aspects: a dynamic situation, related to the context, and individual activities with national and global environment, broader services for guidance such as counseling for financial and overcome stress, exploration and learning to plan, management of anger, insecurity, labor adjustment, and access to every individual in a broader scope.

\section{References}

Afiff, F. (2012). Kewirausaan dan Ekonomi Kreatif. Jakarta: Binus University.

Alias, M. \& Hassan, R. (2013). TVET agency-industry collaborations: addressing diversity. In: TVET@Asia, issue 1, 1-14. Online: http://www.tvet-online.asia/issue1/alias_hassan_tvet1.pdf.

Collin, A. \& Watts, A. G. (1996). The death and transfiguration of career and of career guidance? British Journal of Guidance and Counselling, 24 (3). 385-98.

Gysbers, C, N., Henderson, P. (2001). Leading and Managing Comprehensive School Guidance Programs. Eric Digest. EDO-CG-01-07.

Gutteridge, T., Leibowitz, Z. \& Shore, J. (1993b). When careers flower, organizations flourish. Training and Development Journal, 47, 25-29.

Krumboltz, J. D. (1996). A learning theory of career counseling. In M. L. Savickas \& W. B. Walsh (eds), Handbook of Career Counseling Theory and Practice. Palo Alto. California: Davies-Black.

Kuswana, W.S. (2013). Dasar-dasar bimbingan dan konseling dan kejuruan. Alfabeta. Bandung.

Lent, R. W., \& Brown, S. D. (2008). Social cognitive career theory and subjective wellbeing in the context of work. Journal of Career Assessment. 16 (1).

Paryono. (2013). Anticipating ASEAN Economic Community 2015: Regional initiatives on human resources development and recognition of professional qualifications. In: TVET@Asia, issue 2, 1-8. Online: http://www.tvet-online.asia/issue2/paryono_tvet2.pdf.

Robertson, P.J. (2013). The well-being outcomes of career guidance. British Journal of Guidance \& Counselling, 41 (3), 254-266. Edinburgh Napier University, Edinburgh.

Savickas, M. L. \& Walsh, W. B. (eds) (1996). Handbook of Career Counseling Theory and Practice. Palo Alto, California: Davies-Black.

Savickas, M. L., Nota, L., Rossier, J., Dauwalder, J. P., Duarte, M. E., Guichard, J., Salvatore, S.,Van Esbroeck, R., \& Van Vianen, A. E. (2009). Life designing: A paradigm for career construction in the 21st century. Journal of Vocational Behavior, 75, 239-250.

Super, D. E. (1990). The Psychology of Career: An introduction to vocation development. New York: Harper and Rowe. 